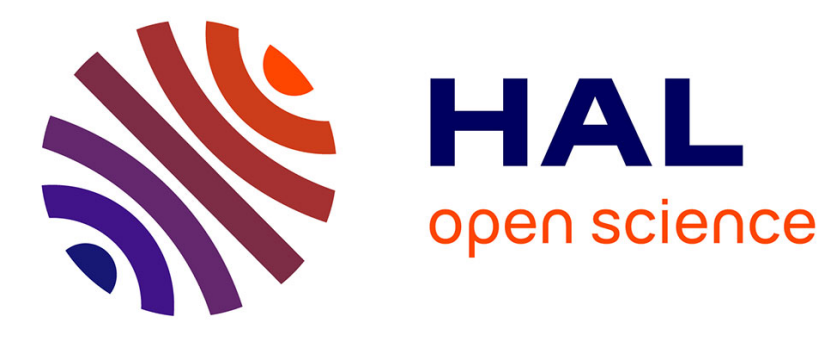

\title{
French Law and its expansion in the Early Modern Period
}

Serge Dauchy

\section{To cite this version:}

Serge Dauchy. French Law and its expansion in the Early Modern Period. Pihlajamäki, Heikki; Dubber, Markus D.; Godfrey, Mark. The Oxford Handbook of European Legal History, Oxford university Press, pp.760-781, 2018, 978-0-198-78552-1. 10.1093/oxfordhb/9780198785521.001.0001 . hal-02967824

\section{HAL Id: hal-02967824 \\ https://hal.univ-lille.fr/hal-02967824}

Submitted on 15 Oct 2020

HAL is a multi-disciplinary open access archive for the deposit and dissemination of scientific research documents, whether they are published or not. The documents may come from teaching and research institutions in France or abroad, or from public or private research centers.
L'archive ouverte pluridisciplinaire $\mathbf{H A L}$, est destinée au dépôt et à la diffusion de documents scientifiques de niveau recherche, publiés ou non, émanant des établissements d'enseignement et de recherche français ou étrangers, des laboratoires publics ou privés. 


\section{French Law and its Expansion in the Early Modern Period}

\section{Serge Dauchy}

The $15^{\text {th }}$ century represents a turning point in the political and institutional history of France. After the Hundred Years War, monarchy embarked on a process of effective assertion of the king's authority over the realm and on institutional centralisation. Charles VII and Louis XI achieved the transformation of France from a medieval feudal monarchy to a modern and centralised State and laid the foundations of the ideological movement toward an absolute and administrative monarchy, i.e. a system where the king is the very centre and heart of political and social life. Such a system has as its crucial underpinning the development of a political, financial and judicial administration staffed by professional and permanent councillors, which is progressively achieved in the second half of the $15^{\text {th }}$ century when irremovibility and security of tenures of judicial and financial functions are guaranteed by the king.

At the same period, the Ordinance of Montils-les-Tours (1454) marks a decisive step in the history of French law by ordering the official recording and homologation of customary law. During the late Middle Ages, French law - as most legal systems in continental Europe - is characterised by legal pluralism. Aside unwritten customary law, Roman law established as scholarly discipline as soon as the $12^{\text {th }}$ century when the first Italian professors from Bologna started to teach the Corpus iuris civilis in southern France and in Paris. In the $13^{\text {th }}$ century already, learned jurists with a legal training in Roman and/or canonical law appear in not inconsiderable number in the king's entourage, appointed in particular in the judicial section of the royal council, the Curia in parlamento. When Louis IX abolished in 1254 the ordeals and introduced the roman-canonical procedure based on rational proofs, ${ }^{1}$ the 'legists' developed the appeal procedure before the king's central court, which asserted his jurisdiction over the ordinary seigneurial and urban courts. They implemented the principles of sovereignty drawn from the Italian glossators and, more generally, adapted existing, mostly unwritten, law to the new requirements of social and economical progress. Roman law however remained, except in procedural matters, to a large extent 'bookish', in the sense that the learned commentaries

\footnotetext{
${ }^{1}$ Raoul van Caenegem, 'History of European civil procedure', in Mauro Cappelletti (ed.), International Encyclopaedia of Comparative Law, XIV : Civil procedure (1973), $12 \mathrm{ff}$. See also Robert Bartlett, Trial by Fire and Water: The Medieval Judicial Ordeal (2014).
} 
on the Corpus were not primarily orientated towards practical every day problems but rather towards exegesis of the Justinian compendium.

At the dawn of Early Modern Times, when graduated lawyers became predominant in the king's private council but also among the judges of the central courts and at the bar, a collision of the two systems, ius commune and iura propria, took place. The term 'collision' should not be misunderstood. It does not refer to intrinsic technical superiority or effectiveness of one system over another. The question rather was, how pursue most efficiently rationalisation and greater uniformity of (private) law. Instead of a reception, i.e. a wholesale adoption of Roman law, beginning with the central courts, the monarchy decided to put the customs in writing and to achieve a first systematic survey by promulgation at the king's command. That the decision was made in favour of customary law can be explained by two basically political reasons. First, a reception of learned law would have implied an official acknowledgement of the superiority of what was considered to be the law of the (German) Empire and the Church. In more practical terms, the king's authority did not extend to all French provinces and impose a unified legal system, moreover based on non-native law, would have been unrealistic. This does not mean that learned law lost its influence or was reduced to the role of academic doctrine. It remained a reserve that could be drawn on for legal argumentation and it was even granted a subsidiary role when customary law appeared to be silent or confused. The history of French law in Early Modern Times is, in other words, the history of the slow (and unachieved) evolution of customary law towards codification and unification. It is also a period of emergence of royal legislation as expression of the king's absolute authority and, as a matter of consequence, a period of tense relations between statute law and judge made law.

\section{The $15^{\text {th }}$ and $16^{\text {th }}$ centuries: The Realm of Customs. From the first transcripts to colonial expansion.}

French legal history has for a very long time focused on a caricature opposition between the Pays de droit écrit in Southern France and the Pays de droit coutumier in the North. Until the early $20^{\text {th }}$ century, historians explained that south of the river Loire, corresponding from a linguistic point of view to the Pays de langue d'oc, Roman law (i.e. the constitutions of the Roman Empire and more particularly the Theodosian Code) had survived during the early 
Middle Ages due to an early and profound Romanisation. In the northern part of the realm, where the dissemination of Roman culture had been less effective, the Germanic invasions would have modelled a legal landscape characterised by a wide diversity of customs. Some of them however had common features or presented similar provisions on particular topics of private law as property law, inheritance law or parental and marital authority, that has led the historians to develop the idea of regional customary groups. ${ }^{2}$

Today, historiography has abandoned the theory of the persistence and continuity of imperial law in the southern provinces. Recent studies about the oldest statutes of the many towns that developed in southern France from the late $12^{\text {th }}$ century on prove the existence of numerous particular customs. The influence of Roman law on these southern customs, as for example in the first written provisions of the custom of Montpellier (1204), is a direct result of its medieval revival, testified by the presence of public notaries and the development of legal education in the late $12^{\text {th }}$ and early $13^{\text {th }}$ centuries. ${ }^{3}$ The distinction between the Pays de droit écrit and Pays de droit coutumier however received effective formalisation by the royal authorities. The decretal Super Speculam (1219) of Honorius III, forbidding to teach and study civil law in Paris, gave a first impulsion to the legal duality between France's southern and northern provinces. ${ }^{4}$ In 1251 , the royal Chancery explicitly recognised that Languedoc was governed by 'written law'5 and in 1278 a specialised section within the king's central court, the Auditorio juris scripta, is created to judge appeals from southern France. ${ }^{6}$ Two centuries later, in 1443, the influence of Roman law in the Pays de droit écrit likewise justified the creation of a second parliament in Toulouse. ${ }^{7}$

\footnotetext{
${ }^{2}$ Such customary groups have for example been identified in the territories under the domination of the Plantagenet in the $12^{\text {th }}$ century: Jean Yver, 'Les caractères originaux du groupe de coutumes de I'Ouest de la France', in Revue historique de droit français et étranger (1953), 18-79.

${ }^{3}$ Jean Gaudemet, Les naissances du droit. Le temps, le pouvoir et la science au service du droit (1997), $31 \mathrm{ff}$. See also Jean Hilaire, La vie du droit. Coutumes et droit écrit (1994), $157 \mathrm{ff}$.

${ }^{4}$ Jacques Krynen, 'La réception du droit romain en France. Encore la bulle Super Speculam', in Revue d'Histoire des Facultés de droit, 28 (2008), 227-262.

${ }^{5}$ Three years later, in 1254, king Louis IX officially recognised the use of Roman Law in the southern provinces of the realm, not because the authority of Roman law is binding, but because it doesn't seem necessary to modify provisions which are in force 'since immemorial times': Jean Bart, Histoire du droit privé de la chute de l'Empire romain au XIXe siècle (1998), $112 \mathrm{ff}$.

${ }^{6}$ Jean Hilaire, La construction de l'Etat de droit dans les archives judiciaires de la cour de France au XIII' siècle (2011), $107 \mathrm{ff}$.

${ }^{7}$ Henri Gilles, 'La création du Parlement de Toulouse', in Jacques Poumarède and Jack Thomas (eds.), Les Parlements de Province. Pouvoirs, justice et société du XVe au XVIII' siècle (1996), $29 \mathrm{ff}$.
} 


\section{Private transcripts, official homologation and customary doctrine}

The concept of 'customary law' is not so simple as it may seem at first sight. Customary law is often defined as 'a legal custom which has become binding through uninterrupted peaceful application over a long time, and as such is opposed to law based on legislation or a judicial pronouncement' ${ }^{8}$ There are clear examples of legal rules whose legislative origin can be demonstrated but which contemporary society considered as custom and it even happened that rules of Roman Law origin came to be represented as customary if sufficiently integrated in practice. This was also the opinion of king Philippe IV who asserted around 1300 that the pays de droit écrit were not to be considered as ruled by learned written law but by customs in conformity with Roman principles introduced by a longstanding tradition and established in practice. ${ }^{9}$ The technical problem of the origin of the rule was in other words less important than its integration in legal and judicial society or evidenced and certified by its incorporation in a written version of a particular custom. In the northern Pays de droit coutumier, the local and regional customs remained for a long time oral and unwritten. The first transcripts, at the private initiative of practitioners, occur in Normandy at the end of the $12^{\text {th }}$ century when the Très Ancienne Coutume is written down. In the mid- $13^{\text {th }}$ century a Summa de Legibus Normanniae is compiled and translated into French between 1270 and 1300 under the name Grand Coutumier de Normandie. ${ }^{10}$ Other Coutumiers (i.e. the private drafting of a particular custom) have been achieved in the $13^{\text {th }}$ and $14^{\text {th }}$ centuries, mostly by judges confronted with the legal uncertainties of the unwritten customs they had to apply in daily practice. Their authors had often studied learned law at the University and they did not hesitate to quote Roman law or the procedural Ordines judiciarii of the Canonists in their compilations. They also refer to royal legislation and decisions of the Parliament of Paris. Some of these private compilations, as Philippe de Beaumanoir's Coutumes de Beauvaisis (drafted ca. 1280) and Jean Boutillier's Somme rural (ca. 1390), ${ }^{11}$ gained great influence in the late Middle Ages and are still quoted as authoritative texts during the early Modern Times. Although these private

\footnotetext{
${ }^{8}$ Raoul C. van Caenegem, 'Bookish Law and Customary Law: Roman Law in the Southern Netherlands in the Late Middle Ages', in Ludo Milis, Daniel Lambrecht, Hilde De Ridder-Symoens and Monique Vleeschouwers-Van Melkebeek (eds.), Law, History, The Low Countries and Europe (1994), $119 \mathrm{ff}$.

${ }^{9}$ Jean Bart (n. 4), 114.

${ }^{10}$ Robert Besnier, La Coutume de Normandie. Histoire externe (1935).

${ }^{11}$ Georges Martyn, 'Jean Boutillier's Rural Summary', in Serge Dauchy, Georges Martyn, Anthony Musson, Heikki Pihlajamäki and Alain Wijffels (eds.), The Formation and Transmission of Western Legal Culture. 150 Books that Made the Law in the Age of Printing (2016), 47-49.
} 
transcripts attempted to set more legal stability, they had no official sanction. At the dawn of Early Modern Times, the monarchy therefore took the initiative of a homologation, i.e. the official recording and promulgation of the customs by the central government. The ordinance of Montils-les-Tours issued by Charles VII in 1454 ordered that all customs of the realm should be put down in writing by local practitioners and approved by local assemblies composed of representatives of the three Estates. If any disagreement appeared about the custom's provisions, they had to be resolved by the central courts. The official drafting and registration process ordered by the central authorities undoubtedly contributed to more legal security and facilitated the work of lawyers, it did not achieve legal unification. Minor customs were abandoned and archaic provisions abolished, but customary diversity remained. Moreover, the process launched in 1454 was not put into full force before the $16^{\text {th }}$ century, when about sixty general customs were recorded and formalised. Homologation nevertheless was a decisive stage in French legal history as it gave the customs, at least some of them, binding force in the courts. Judges and advocates were not allowed any more to refer in practice to customs that had not been officially sanctioned and recorded. The principal advantage was that it put an end to the existing uncertainty to what extend learned law could be applied and what was to be done when the customs provided no clear solution. That the decision was clearly made in favour of customary law can, as said previously, be explained by political reasons but foremost by the high qualitative level of some homologated customs.

In the $16^{\text {th }}$ century, the first officially sanctioned customs are published with substantial commentaries, giving rise to a new kind of legal literature known as customary doctrine. In France, as in most continental countries, academic legal learning and legal literature had until then exclusively focused on Roman and canonical law. During the late Middle Ages, the most prominent authorities were Italian and their specific approach (mos italicus), overwhelmingly influenced by the late-medieval scholastic methods, prevailed in legal education. From the early $16^{\text {th }}$ century onwards, an alternative method is progressively developed, referred to as 'Legal humanism'. In France, Jacques Cujas broke with the old medieval approach. Applying the principles of historical criticism to Roman law, he removed the Corpus Iuris Civilis from timelessness and underlined the different stages of the construction of the learned legal system within its specific historical context. ${ }^{12}$ Learned doctrine had understandably some

\footnotetext{
${ }^{12}$ Xavier Prévost, Jacques Cujas (1522-1590) : jurisconsulte humaniste (2015) and Idem, 'Jacques Cujas' Observationum et Emendationum Libri XXVIII', in Dauchy e.a. (n. 10), 82-85
} 
impact on the emerging customary doctrine. Charles Dumoulin's Commentaries on the custom of Paris, published in 1539, is the first important contribution to a scholarly study of customary law. Although using the same methods as those applied by the Romanists for the study of the Corpus Iuris Civilis, Dumoulin's main purpose was to defend customary law against the raising influence of learned law in academic circles as well as in practice. It may therefore seem ironic that he used Latin, the ius commune language, rather than vernacular. Charles Dumoulin tried to provide theoretical grounds for a 'common' customary law, shaped as compromise between customary provisions and the inputs of ius commune. In that perspective, the use of Latin certainly contributed to a wider dissemination of his work. ${ }^{13}$ Pursuing the same objectives and building on the experience gained by the Humanist School, Antoine Loysel strove to put the diversity of customary provisions into principles. His Customary Institutes were first published in 1607 together with Guy Coquille's Institution au droit français which equally promoted a progressive unification of law based primarily on national customs. In accordance to these models, commentaries were progressively published on the main customs of the realm and their implementation illustrated by decisions of the provincial parliaments. At the end of the $17^{\text {th }}$ century, Eusèbe de Laurière and Claude Berroyer took the initiative towards the editing, in one single collection, of all the general and particular customs of France and in 1699 they issued a first draft entitled Bibliothèque des Coutumes (Library of the customs). Charles-Antoine Bourdot de Richebourg took over their project and published in 1724 the Nouveau Coutumier Général, presenting in 4 volumes the main homologated customs since the $15^{\text {th }}$ century.

\section{The leading position of the custom of Paris and its colonial expansion}

In 1580, Christophe de Thou, president of the Parliament of Paris, supervised a new draft of the custom of Paris, first compiled in 1510. As custom of the capital of the realm and seat of the royal institutions - also because of the popularity of Charles Dumoulin's commentaries the 'New custom of Paris' soon acquired a leading position in France's legal landscape. That position is even more apparent in the early years of French colonial history when the custom

\footnotetext{
13 Jean-Louis Thireau, Charles Dumoulin (1500-1566). Étude sur les sources, la méthode, les idées politiques et économiques d'un juriste de la Renaissance, (1980) and Marie Seong-Hak Kim, 'Charles Dumoulin's Commentaries on the Custom of Paris', in Dauchy e.a. (n. 10), 82-85.
} 
of Paris became one of the main expressions of the expansion of French law in Early Modern Times.

In 1627, Cardinal Richelieu had conceded in plain property the French territories in NorthAmerica to the Company of New France which, in return for a monopoly on fur trade, was committed administration of the colony. Unable to settle the colony and fulfil its mandate, the company was finally revoked in 1663 and a royal intendant appointed. One of the first royal decisions regarding the crown colony was the establishment of a Sovereign Council by edict of April 1663. The colonial Council acted as court of appeal for the French territories in North-America and issued general regulations dealing with all aspects of the colony's economic, social, religious, administrative and judicial organisation. ${ }^{14}$ Aware of the local particularities, the central government in Versailles introduced when necessary some adjustments to the metropolitan legal and judicial practices or even experienced some innovations. ${ }^{15}$ One of the main issues to which the royal authorities accorded special attention was the question of the law in force in the colony. Before 1663, the Company of New France had tried to impose the custom of Paris as single applicable law, but it never succeeded. The presence of settlers and merchants of different geographic origin, each willing to use in daily life and in their commercial activities the customs of the province they originated, and the jurisdiction of the Parliament of Normandy, competent authority for the overseas colonies, were important resistance factors for any attempt to achieve legal standardisation. The edict of Foundation of the Quebec Council (1663) moreover did not impose a particular legal system; it only directs the judges to obey the royal statutes and proceed accordingly to the procedural formalities in force in the parliament of Paris. ${ }^{16}$ One year later however, in May 1664, the royal charter establishing the French West India Company made a decisive step toward a uniform legal system. Article 33 provides that the inhabitants of New France have to comply with the custom of Paris and expressively prohibits to introduce any other customary provisions. In other words, the central government formalised the transplant of French law in

\footnotetext{
${ }^{14}$ Raymond du Bois Cahall, The sovereign council of New France. A study in Canadian Constitutional History (1915).

15 David Gilles, 'Les acteurs de la norme coloniale face au droit métropolitain: de l'adaptation à I'appropriation (Canada XVII -XVIII siècle)', in Clio@Thémis. Revue électronique d'histoire du droit, 4 (2011).

${ }^{16}$ Edits, ordonnances royaux, déclarations et arrêts du conseil d'Etat du roi concernant le Canada, vol. 1 (1854), 37-39. Cf. Serge Dauchy, 'Le Conseil souverain de Québec. Une institution de I'ancienne France pour le Nouveau Monde', in Revue du Nord, 97 (2015), 513-526.
} 
North-America, the custom of Paris becoming the only legitimate source of law in New France. ${ }^{17}$ In 1712, the custom of Paris is also designed by the king as applicable law to Louisiana and it lasted there until it was replaced by Spanish law in $1763 .{ }^{18}$ Even when in 1763 New France was ceded to the British by the terms of the Treaty of Paris and Common law was initially introduced, the Québec Act of 1774 restored, after considerable controversy among French and British lawyers, French private law pertaining to property and civil rights by allowing the 'French Canadians' to cite the Laws and Customs of Canada. ${ }^{19}$ In 1866, the Civil Code of Lower Canada came into force. It took over the general presentation of the Napoleon Code civil of 1804, but also incorporated French customary law, case law of the Sovereign Council and royal statute law prior to 1763 . The imprint of the custom of Paris can still be observed in the reformed Code of $1994 .{ }^{20}$

\section{The role of case law in early modern France}

Judicial decisions, at least at the level of the central courts, have played a significant role in the development of French law. As appellate court, the parliament of Paris adapted the procedural rules in force before the ecclesiastical courts and laid down the foundations of modern (so-called Roman-canonical) civil procedure. When setting out the principles of civil procedure before the Flemish courts in the late $15^{\text {th }}$ century, Philips Wielant ${ }^{21}$ systematically

\footnotetext{
${ }^{17}$ Jacques Vanderlinden, 'La réception des systèmes juridiques européens au Canada', in Tijdschrift voor Rechtsgeschiedenis / Legal History Review, LXIV (1996), 359-389; Antoine GérinLajoie, 'Introduction de la coutume de Paris au Canada', in Revue du barreau de la province de Québec (1941), 61-65 and Yves Zoltvany, 'Esquisse de la coutume de Paris', in Revue d'Histoire de l'Amérique française, 25-3 (1971), 365-384

${ }^{18}$ Jerah Johnson, 'La Coutume de Paris: Louisiana's first Law', in The Journal of the Louisiana Historical Association, 30 (1989), 145-155 and John H. Tucker, 'The Code and the Common Law in Louisiana', in Bernard Schwartz, The Code Napoléon and the Common-Law World (1998), $346 \mathrm{ff}$.

${ }^{19}$ Gerald E. Hart, The Quebec Act, 1774 (1923). See also David Gilles, 'Quand comparaison n'est pas raison. Les juristes britanniques et canadiens comme analystes des systèmes de Common law et de droit civil en amont de l'Acter de Québec (1774)', dans Clio@Themis. Revue électronique d'Histoire du droit [www.clithemis.com] 12 (2017).

20 Jean-Guy Cardinal, 'Le droit civil au Québec. Ses sources, son evolution, son originalité', in Revue juridique et politique, 21-3 (1967), 417-424 and John E. Brierly and Roderick A. Macdonald, Quebec civil Law. An Introduction to Quebec Private Law (1993).

${ }^{21}$ Philip Wielant's Pracktijcke civile, written in Dutch and intended for Flemish judges, lawyers and court officials, was only available in manuscript form. Joos de Damhouder translated Wielant's work in Latin (Praxis rerum civilium) and published it in 1567 under his own name before editing a French and German translation in 1572, also without mentioning the name of Wielant. The plagiarism was not discovered before the late $19^{\text {th }}$ century. A shorter version written by Wielant in French to the attention of young practitioners was published by Louis Sicking and Cornelis H. van Rhee, Briève instruction en causes civiles (2009).
} 
refers to the procedural 'style' and to case-law of the Paris' parliament and in the $16^{\text {th }}$ century procedural rules before the Great Council for the Netherlands still bear the imprints of the late medieval Stilus Curie Parlamenti. ${ }^{22}$ The parliament of Paris' case law furthermore contributed to establish and interpret customary provisions way before the main customs of the realm were drafted and enacted. Its binding judgements (arrêts de règlement) moreover laid down the arrangements for implementing them before the lower courts. Empowered to dispense justice on behalf and in the name of the king, the parliament also ensured royal lawenforcement and asserted the king's sovereignty and jurisdiction over the feudal lords and the ecclesiastical authorities. It should also be mentioned that the high judges were open to Ius commune in legal practice, as prove the frequent use of allegations of Roman law, canonical law and medieval learned treatises in the written statements of the advocates.

Not surprisingly private collections of case law soon circulated among practitioners as Johannes Galli's Questiones, the oldest known collection of decisions, presenting cases judged by the parliament of Paris between 1382 and $1396 .{ }^{23}$ With the printing revolution, the manuscript collections of court decisions, gathered by judges and advocates for their private use, gave birth to a new genre of legal literature commonly called 'arrestography' because their authors mainly collected decisions or arrêts of the central courts. It has been suggested that these collections had been launched on the initiative of printers and booksellers. With the decline of the learned Italian treatises and the growing concern for customary law in the $16^{\text {th }}$ century, they looked for new commercial opportunities on the legal book market and new legal genres that could spark the interest of a wider public of practitioners. Booksellers promoted their compendia as useful for both young and more experienced lawyers who might find in these printed collections precedents as well as materials for legal argumentation. Printed collections of central court decisions became a very popular genre in Early Modern Times, following the growing number of royal parliaments. After the Hundred Years War, the expansion of the king's jurisdiction led to the establishment of new parliaments in the peripheral provinces placed progressively under direct royal authority: Grenoble (1453), Bordeaux (1462), Dijon (1477), Aix-en-Provence (1501), Rouen (1515) and Rennes (1554).

\footnotetext{
${ }^{22}$ Cornelis H. van Rhee, Litigation and legislation. Civil Procedure at First Instance in the Great Council for the Netherlands in Malines, 1522-1559 (1997).

${ }^{23}$ At the initiative of Charles Dumoulin, the Questiones Johannes Galli were first published in 1551, together with Guillaume du Breuil's Stilus curie parlamenti parisiensis, proof of the importance of Case law for customary doctrine. Cf. Marguerite Boulet-Sautel, Questiones Johannes Galli (1944).
} 
Under the reign of Louis XIV other central courts are created in the newly conquered territories of Alsace, Roussillon and Flanders ${ }^{24}$ and in the colonies. The printed collections of central court decisions express this judicial and institutional diversity. Most authors, whether judges or advocates, chose to gather the decisions of a single court. Their purpose is mainly practical if not purely commercial: present abridgements of some cases which, for different reasons, are likely to attract the curiosity of local practitioners. Others tried to seek out some systematisation and highlighted decisions that might have a wide-range application. Jean Papon's Receuil d'arrêts notables printed in 1556 is from this perspective particularly illustrative. Advocating the development of a national case law modelled on Dumoulin's attempts to achieve a general custom of France, Papon even so rejected the scholastic tradition and instead proposed short-cut principles (preceding somehow Antoine Loysel's adages) that could be applied nationwide.

In the $17^{\text {th }}$ century, the printed collections of case law experience a significant growth and express the arrestographs' willingness to systemise jurisprudence by structuring their work around legal questions presented in alphabetical order, with the clearly stated aim to assert its role as source of law. As pointedly observed by Jean Carbonnier, arrestography has to be understood as 'the art or science to suggest all judicial possibilities and their contrary and to emphasise the most likely in order to move court decisions in that direction'. ${ }^{25}$ We should indeed not forget that during the late Middle Ages and Early Modern Times, judges did not disclose the rationes decidendi and will never do so before the French Revolution forced the judges to reveal the reasons of their decisions. ${ }^{26}$ Many authors and editors therefore promoted their enterprises by stating that they sought to disclose, or at least reconstruct, the rationes decidendi of major court decisions. Some titles of this new generation of printed case law collections have known innumerable reprints, each of them revised and enriched with new decisions and learned commentaries written by practitioners often commissioned by the editors. Georges Louet's collection of decisions of the parliament of Paris for example, first published in 1602 and presenting initially only cases Louet had himself judged, has been regularly republished (14 reprints) until 1740, each time enriched with new topics and new

\footnotetext{
${ }^{24}$ Although they are granted the title Sovereign Council (Conseil souverain), they have the same prerogatives and privileges as the parliaments.

${ }^{25}$ Jean Carbonnier, 'Note sur des notes d'arrêts', in Recueil Dalloz (1970), 138.

${ }^{26}$ Serge Dauchy and Véronique Demars-Sion, 'La non-motivation des décisions judiciaires sous I'Ancien Régime: usage ou principe? in Revue historique de droit français et étranger, 82 (2004), 223-239.
} 
decisions. ${ }^{27}$ His book stood model for similar initiatives in France $^{28}$ and even enjoyed international circulation. Others tired to contribute to the construction of a national law by presenting converging court decisions on a same legal question. The Journal du Palais, for example, was an ambitious initiative undertaken in the late $17^{\text {th }}$ century by two Parisian advocates, Gabriel Guéret and Claude Blondeau, in order to bring together in a single collection the jurisprudence of the different parliaments. In the $18^{\text {th }}$ century, the printed collections of case law progressively gave way to dictionaries which aimed, as did the encyclopaedists, to present a comprehensive and methodical survey of a (theoretically) unified jurisprudence based on a selection of central court decisions. Their authors attempted to set out principles rather than commenting series of similar case law decisions.

It is difficult to assess the contribution of case law to the construction of French law, even more to measure the significance of the decisions of the different parliaments to the unification and consolidation process of private law. As has already been stressed, Ancien Régime judgements do not reveal the rationes decidendi and never present dissenting opinions among judges. They could thus never gain recognition as binding judicial precedents. Consequently, some legal historians prefer the term 'jurisprudence of the arrestographs' rather than 'jurisprudence of the court decisions (arrêts)'. Many authors of printed case law collections have sought to sweep away or at least minimise conflicting jurisprudence or contradictory interpretations of legal provisions by the courts. They often stress the most desirable legal solution and do not hesitate to present as ratio decidendi the most appropriate legal reasoning, i.e. the one expressing the convergence of customary and ius commune opinions. Arrestography should thus primarily be considered as legal doctrine, aiming as the commentaries on customary law to enhance legal systematisation and unification.

\footnotetext{
${ }^{27}$ Serge Dauchy, 'Le Parlement de Paris aux Temps modernes : collation de recueils privés et de registres de la Cour', in Alain Wijffels (ed.), Case-Law in the Making. The Techniques and Methods of Judicial Law Records and Reports, Comparative Studies in Continental and Anglo-American Legal History, 17/I (1997), 269 ff. and Serge Dauchy, 'L'arrestographie, un genre littéraire?', in Revue d'histoire des Facultés de droit et de la culture juridique, 31 (2011), 41-54. See also Serge Dauchy and Véronique Demars-Sion (eds.), Les recueils d'arrêts et dictionnaires de jurisprudence, XVI $-X V I I I^{e}$ siècles (2005).

${ }^{28}$ Georges de Ghewiet, for example, followed Louet's model to achieve a collection of decisions of the parliament of Flanders: Serge Dauchy and Véronique Demars-Sion (eds.), La jurisprudence de Flandre de George de Ghewiet, Commission royale pour la publication des Anciennes Lois et Ordonnances de Belgique (2008).
} 


\section{The $17^{\text {th }}$ and $18^{\text {th }}$ centuries: The Age of Royal Legislation. Towards codification and rationalisation of French law}

At the dawn of Early Modern Times, a significant body of royal legislation already exists, going back to the $12^{\text {th }}$ and $13^{\text {th }}$ centuries. These ordinances and edicts relate to public law and systematically refer to the Roman principle of utilitas publica..$^{29}$ They mainly concern sovereign rights as justice, administration, fiscal and monetary policy or feudality. In the $15^{\text {th }}$ century, the king's legislative activity experiences a substantial growth, expressing a new approach of royal power and sovereignty. Whereas in the Middle Ages the figure of the king was primarily associated with justice through the representation of Saint Louis rendering justice under the oak of Vincennes, in Early Modern Times the monarch is seen and imaged as legislator, premise of the development of royal absolutism. After the Hundred Year War, in particular from the reign of Louis $\mathrm{XI}$, the monarchy endeavours to strengthen its position as law-maker. Absolute monarchy indeed attempts to achieve greater control of the royal administration on the Nation rather than an extension of the king's personal authority. This means the monarchy's priority is to provide the state with a centralised institutional machinery and with efficient legal instruments. In this context, legislation soon appears to be the best expression of the king's sovereignty and the most effective instrument of his political agenda. One century later, Jean Bodin will theorise the foundations of royal absolutism and State sovereignty. In The Six Books of Commonwealth, his most prominent contribution in the field of political philosophy and public law, Bodin brings back the idea of maiestas to the original definition of the Digest's principle Princeps legibus solutus. He states that sovereignty consists in the power to give and to change the law without the consent of his subjects. ${ }^{30}$ Legislation (lex) is thus the command of a sovereign prince, the expression of his absolute power which, according to some of Bodin's successors as Guy Coquille, Cardin Le Bret and finally JacquesBénigne Bossuet, only finds its limits in the laws of God and nature.

Any initiative to collect and unify the many, often extremely diverse, statutory dispositions has long been neglected. Except for some ordinances about judicial organisation and

\footnotetext{
${ }^{29}$ Albert Rigaudière, 'Législation royale et construction de l'Etat dans la France du XIII' siècle', in André Gouron and Albert Rigaudière (eds.), Renaissance du pouvoir législatif et genèse de l'Etat (1988), 203 ff.

${ }^{30}$ Julian H. Franklin, Jean Bodin and the Rise of Absolutist Theory (2009); Diego Quaglioni, 'Jean Bodin's Six Books of Commonwealth', in Dauchy e.a. (n. 10), 126-129.
} 
procedural formalities, ${ }^{31}$ legislation in the $16^{\text {th }}$ century still deals with disparate matters, both general and particular, also because learned doctrine is still characterised by a lack of systematisation of the different branches of law. In 1587, Henri III commissioned Bernabé Brisson, a royal judge and author of treatises on Roman law, to bring together the former ordinances and edicts and to publish them in a systematic and chronological order. Brisson also tried to eliminate obsolete provisions, harmonise contradictory dispositions and point out deficiencies of the current statutes. Due to the author's involvement in the political and religious turmoil of the late $16^{\text {th }}$ century, the Code Henri was never enacted and remained a private compilation. Moreover, his work, as later achievements - the Code Henri IV (1615) and Code Louis XIII (1628) - can hardly be called a 'Code'. They nevertheless paved the way or at least sparked the idea about the necessity of a real implementation of statutory codification in France.

\section{The Great Ordinances of the $17^{\text {th }}$ century or the 'Codification policy' of Louis XIV}

The Codification process was effectively initiated in the mid- $17^{\text {th }}$ century. It reflects Louis XIV main political and ideological objectives: unification, centralisation and systematisation. ${ }^{32}$ The king and his closest councillors were indeed convinced that a rational body of codified statute law was the most solid foundation to ensure the continuation of the State, peace of the families and happiness of the Nation. Royal legislation was to be considered as the main source of law, because it was the highest expression of the king's absolute authority, and therefore had to go far beyond the traditional scope of public law to cover all the branches of law. The codification process moreover fitted in France's mercantile policy. The government's new economic and commercial vision, closely linked to the establishment of overseas colonies, was indeed inconsistent with legal insecurity provoked by a lack of codified legislation and uniform procedural rules. Not surprisingly, Jean-Baptiste Colbert, ControllerGeneral of Finances (1665) and later also Secretary of State of the Navy in charge of the rising colonial Empire and international trade (1669), was the driving force behind the codification process and also the main architect of its success.

\footnotetext{
${ }^{31}$ In particular, the Ordinance of Villers-Cotterêts (1539) that also required the use of French in justice and administration, and the Ordinances of Moulins (1566) and Blois (1579). Cf. Alain Wijffels, Introduction historique au droit. France, Allemagne, Angleterre (2014), $131 \mathrm{ff}$.

32 Jean-Louis Halpérin, Five Legal Revolutions since the 17th Century. An Analysis of a Global Legal History (2014), 35 ff., considers codification as 'a revolution through systematisation'.
} 
The first of these "codes", enacted in 1667, is the Ordinance for the Reformation of Justice (Ordonnance pour la reformation de la justice), better known as Ordinance of Civil Procedure, that replaced in all royal jurisdictions, also in the colonies, the procedural styles particular to each court with a clear and uniform procedure. ${ }^{33}$ If the declared aim was to reduce the length and costs of civil litigation and achieve a better enforcement of the judgements, the king's main objective was to affirm the supremacy of royal legislation over judge-made law. The first chapter of the Ordinance entitled "Compliance with the royal ordinances", imposes faithful compliance with royal statutory law and prohibits under whatever guise to override or moderate the law. Moreover, any interpretation of royal legislation by the judges is strictly forbidden. When a difficulty or doubt arise, judges should refer directly to the king to know about his will and intentions. Finally, the Civil Ordinance also paves the way to the possibility of a cassation before the king's Council against the 'sovereign' decisions of the parliaments, hitherto considered to be the highest and final judicial instance. The Ordinance of 1667 has therefore rightly be seen as a 'royal war machine' against the central court justices who claimed to be consulted and even associated with any law-making activity. ${ }^{34}$ The first royal 'Code' conceived the idea that judges should only be the mouth of the law, i.e. 'applying mechanically legal dispositions to a particular case' to use Beccaria's syllogistic scheme. Louis XIV set out the seed of a crucial principle that Montesquieu, himself a councillor at the parliament of Bordeaux, will take up and further develop in his Spirit of Laws. In a way, the royal ordinance thus prepared some major changes that will take place after the French Revolution when the overall superiority of the law is proclaimed as expression of the Nation's will.

The new provisions on civil procedure have been implemented in all the courts of the realm, also in the colonies after minor adaptations to their remoteness and the local particularities. The Ordinance of 1667 can therefore be considered to be the first concrete implementation of legal and judicial unification. Moreover, the $17^{\text {th }}$ century procedural reforms provided the main materials and even the structure of the Code de procedure civile passed in 1806 . The

\footnotetext{
${ }^{33}$ Raoul van Caenegem (n. 1), 45 ff.

${ }^{34}$ Jacques Krynen, 'La haute magistrature contre la codification. Autour de l'Ordonnance civile (1667)', in Aquilino Iglesia Ferreiros (ed.), El dret comú i Catalunya (2005), 175 ff. and Jacques Krynen, L'idéologie de la magistrature ancienne (2009), 139 ff. See also Raoul C. Van Caenegem, Judges, legislators and professors. Chapters in European legal history (1987), 152 ff. 'Codification: a weapon against the judiciary'.
} 
drafters of the Code - all of them Ancien Régime practitioners - indeed did not change the general conception of civil litigation, except for the principle of oral rather than written proceedings; they also took over most of the ancient procedural formalities and remedies. ${ }^{35}$ For the Napoleonic Code of Civil Procedure was introduced in most European countries and often remained unchanged until the second $20^{\text {th }}$ century, it can be considered as one of the main and most influential expressions of the expansion of Early Modern French law. ${ }^{36}$

After having carried out a systematisation of civil procedure, the same commission composed only of State Councillors (not judges) and chaired by Henri Pussort, Colbert's uncle, started to draft a new criminal code in order to replace the former texts on criminal law and procedure going back to 1539 . Three years later, in 1670, the Criminal Ordinance was enacted by the parliament of Paris. Its provisions have been unanimously acknowledged as extremely harsh and repressive. The secret and written procedure, the lack of the rights of the defence, the use of judicial torture and the cruel punishments have been criticised, in particular by philosophers in the Age of Enlightenment. The criminalists of the late $17^{\text {th }}$ century, on the contrary, emphasised some significant progresses. The use of judicial torture to extort confessions was placed under strict control of the central courts and sentences to corporal punishments, banishments or galleys had henceforth to be confirmed by a parliament, placing thus criminal repression under close supervision of the central authorities or at least of the high judges.

The main - economic - objectives pursued by Colbert's codification efforts were achieved through two ordinances on commercial matters. The Ordinance for Overland Trade or Code Marchand is issued in 1673. Colbert had commissioned Jacques Savary, a merchant from Paris who had written several essays on commercial topics, to prepare the ordinance (therefore also called Code Savary) in close cooperation with the commercial courts (juridictions consulaires). ${ }^{37}$ The new commercial legislation was soon considered to be deficient and incomplete, probably because of its author's background and personality. It

\footnotetext{
${ }^{35}$ Jean-Louis Halpérin, 'Le Code de procédure civile de 1806: un code de praticiens?' and Serge Dauchy, 'La conception du procès civil dans le Code de procédure civile de 1806', in Loïc Cadiet and Guy Canivet (eds.), De la commémoration d'un code à l'autre: 200 ans de procédure civile en France (2006), $23 \mathrm{ff}$. and $77 \mathrm{ff}$.

${ }^{36}$ Cornelis H. van Rhee (ed.), European Traditions in Civil procedure (2005); Cornelis H. van Rhee, Dirk Heirbaut and Marcel Storme (eds.), The French Code of civil procedure (1806) after 200 years. The civil procedure tradition in France and abroad (2008).

${ }^{37}$ Jean Hilaire, Introduction historique au droit commercial (1986), $34 \mathrm{ff}$.
} 
nevertheless brought some unity and coherence in commercial law after the disparate laws on bankruptcy, enforcement by committal and arbitration of the $16^{\text {th }}$ century and even served as a model for the Prussian legislation of the $18^{\text {th }}$ century. The Ordinance for Maritime Trade, also called Code de la Marine (1681), on the contrary, has been unanimously praised by legal doctrine. Expressing the growing importance of international trade and the globalisation of commercial practises, it was largely inspired by Dutch and English law. Both royal ordinances will form the basis of the Code de commerce of 1807 , often described as a shy and roughly revision - following the monarchical tradition also drafted by practitioners commissioned by Napoleon - of the $17^{\text {th }}$ century legislation. ${ }^{38}$

Finally, one should also mention the Ordonnance touchant la police des îles de l'Amérique issued after Colbert's death in 1685 which even so expresses the particular interest of the monarchy for the West-Indies and their important place in the mercantile policy initiated by Colbert. The Ordinance mainly regulates slavery in the French Antilles, ranging from topics such as the rights and obligations of the masters, the status of the freed slaves or the penalties of convicted slaves, and is for that reason commonly known as 'Black Code'. French legislation influenced the regulations on slavery in the neighbouring territories and in particular the Louisiana regulations of $1724^{39}$.

\section{A review of Colbert's reforms: an important but incomplete effort to codify and systematise French law}

The great ordinances-codes of the second $17^{\text {th }}$ century are an important milestone in French legal and political history. Colbert conceived the idea of a comprehensive and rigorously planed codification in all areas of the law, whose main objective was a truly systematisation of law and the centralisation of justice. The considerable work accomplished by the Council of State in a short period of time was of high quality and easily transposable in practice. The best proof of this is their influence on the Napoleonic codification, both regarding the idea of drafting a separate code for each particular branch of law as the legal substance of some of them. The only notable deficiency of Colbert's codification efforts concerned the lack of a reliable unification and systematisation of private law. A complete

\footnotetext{
${ }^{38}$ Antonio Padoa-Schioppa, 'Napoleone e il Code de commerce', in Diritto e potere nella storia europea $\left(1982^{\circ}, 1041 \mathrm{ff}\right.$.

${ }^{39}$ Junius P. Rodriguez (ed.), Slavery in the United States. A social, political and historical Encyclopedia (2007)
} 
codification of private law will never be achieved before 1804 , showing in a kind of way the legal and political boundaries of the absolute monarchy. From a constitutional point of view, the king is guardian of the customs and guarantor of the particularities of each province, which underlay Ancien Régime society and State organisation. ${ }^{40}$ Therefore, monarchy only ventured down the path of codification of private law with extreme caution. D'Aguesseau, chancellor of Louis XV, drew up an Ordinance on Donations (1731), on Wills (1735), on Falsifications (1737) and on Trustees (1747), but never achieved an overall codification of private law neither a unification of the parliaments' jurisprudence on customary provisions.

The reign of Louis XIV was also a turning point as to the hierarchy between the sources of law. Until the $17^{\text {th }}$ century, customs and Roman law were considered to be the main sources of legal thought and legal practice. The parliaments moreover had extensive statutory authority which expressed their arrêts de règlements (regulatory decisions) ${ }^{41}$. The king's codification willingness asserted royal legislation as main source of law and thus claimed the exclusive legislative jurisdiction of the king. Under the reign of Louis XV however, the parliaments will try again to intervene in the law-making process by recalling their right to verify whether the royal ordinances do not contravene the fundamental laws of the realm. ${ }^{42}$

Last but not least the great ordinances of the late $17^{\text {th }}$ century generated the development of commentaries and doctrinal treatises on the relevant areas of law concerned by the codification achievements of the Council of State. Philippe Bornier's Conferences on the civil and criminal ordinances of 1667 and 1670, published in 1678, soon gained great notoriety and provided the basis of François Serpillon's Criminal Code published in $1767^{43}$. In 1675 Jacques Savary, the main drafter of the Code marchand, published a commentary of the ordinance of 1673 under the title 'The Perfect Trader' that aroused the attention of lawyers for business and corporate law. After having renewed in 1753 Bornier's observations on the civil and criminal ordinance, Daniel Jousse published in 1756 a new and notable commentary on the

\footnotetext{
${ }^{40}$ Jean-Louis Halpérin, Histoire du droit privé français depuis 1804 (1996), $15 \mathrm{ff}$.

${ }^{41}$ Philippe Payen, Les arrêts de règlements du Parlement de Paris au XVIII siècle (1997).

${ }^{42}$ Confronted with the abusive remonstrations of his parliaments and their systematic refusal to enact the royal ordinances, Louis XV hammered in his famous 'flagellation speech' (1766): C'est à moi seul qu'appartient le pouvoir législatif, sans dépendance et sans partage. Cf. Serge Dauchy, 'Séance royale du 3 mars 1766 devant le Parlement de Paris dit séance de la Flagellation', in Julie Benetti, Pierre Egéa, Xavier Magnon et Wanda Mastor (eds), Les Grands discours juridiques, Dalloz, collection les grands arrêts (2017).

${ }^{43}$ Philippe Bornier, Conférences des Ordonnances de Louis XIV, 2. Vol. (1678) ; François Serpillon, Code criminel ou commentaire sur l'ordonnance de 1670, 4 vol. (1767).
} 
1673 Ordinance of Commerce ${ }^{44}$ whereas Robert Pothier, best known for his Treatise on Obligations, published in 1764 a Treatise on Partnership Agreement. ${ }^{45}$ These treatises have contributed to promote the implementation of the codification idea and prudently paved the way to an overall systematisation and unification of a national law.

Last but not least, the great ordinances also had a major influence on legal education. By his Edict of Saint-Germain-en-Laye (1679), the king established an academic chair in French law in all the law faculties of the realm. The chair-holders, appointed directly by the royal Chancellor, were commissioned to teach, in vernacular, French law, i.e. royal legislation and customs. ${ }^{46}$ We can presume that these chairs influenced later developments in French and continental legal education, in particular the $19^{\text {th }}$ century Exegetic School. The way professors thought the Napoleonic codes in the $19^{\text {th }}$ century is not that much different from the way lawyers commented the great ordinances in the $18^{\text {th }}$ century.

\section{The contribution of the French enlightened philosophers to the evolution of law and} justice in the $18^{\text {th }}$ century

In the $18^{\text {th }}$ century, enlightened philosophers advanced new ideas about government and law centred on 'reason'. In France, enlightened writers - some of them lawyers - criticized in particular the arbitrary authoritarian state and contributed to undermine the authority and legitimacy of absolute monarchy 'of divine right', advocating especially separation between State and Church. Jean-Jacques Rousseau as John Locke developed a social contract theory based on the principle of 'natural rights', arguing that the government's authority lies in the consent of the governed. As a matter of consequence, law should always be the expression of the people's will and judges subject to the law. Also building on John Lock's Treatises of Government, Montesquieu argues in his Spirit of the Laws (1748) that political and individual liberty can only be secured when the executive, legislative and moreover judicial functions are assigned to different bodies. Montesquieu in other words developed the principle of separation or balance of powers at a time when the king claimed exclusive legislative authority and central courts still judged in his name.

\footnotetext{
${ }^{44}$ Daniel Jousse, Nouveau commentaire sur l'ordonnance du commerce du mois de mars 1673 (1756).

${ }^{45}$ Robert Pothier, Traité du contrat de société, selon les règles tant du for de la conscience que du for extérieur... par l'auteur du Traité des obligations (1764).

${ }^{46}$ Christian Chêne, L'enseignement du droit français en pays de droit écrit, 1679-1793 (1982).
} 
Besides public law and political theories, enlightened authors were particularly interested by criminal law. In book XII of his Spirits of the Laws, Montesquieu sets out his view on criminal legislation which, in his mind, should be the very expression of the enlightened principles of rationality, humanity, liberty and progress. He therefore condemns, as others will do, secrete procedure, the use of torture, the judges' discretion and arbitrary decisions, the lack of rights of defence and the cruel and infamous penalties. ${ }^{47}$ The case of Jean Calas (1761-1762) is a perfect illustration of repressive criminal law under the Ordinance of 1670 and of what enlightened philosophers but also more and more lawyers denounced. Jean Calas was a protestant merchant of Toulouse accused of having murdered his own son in order to prevent his conversion to the Roman Catholic faith. ${ }^{48}$ After having been tortured, and although protesting his innocence, he was found guilty of parricide and sentenced to be broken on the wheel. Voltaire took up the case and alerted public opinion. By his vigorous intervention, and after the king's Council had ordered a revision, he obtained in 1765 the rehabilitation of Jean Calas and a pension for his family. ${ }^{49}$ Another affair where Voltaire protested actively, but in vain, concerned the nineteenth year old Chevalier de la Barre who was beheaded in 1766 for having insulted a religious procession and damaged a crucifix. ${ }^{50}$ Both cases express the enlightened philosophers' chosen themes: the establishment of religious tolerance and, from a legal and judicial point of view, the respect of human rights by the abolition of torture and cruel punishments.

Cesare Beccaria who wrote the first systematic statement of principles governing criminal law and procedure and laid the foundations of modern criminology and penology, is indebted to the French philosophers and in particular to Montesquieu who he repeatedly acknowledges in his book Of Crimes and punishments published - first also anonymously - in 1764. His innovative views on criminal law are influenced by Rousseau's and Bentham's utilitarian principle that government should seek the greatest good for the greatest numbers, i.e.

\footnotetext{
${ }^{47}$ Stéphanie Blot-Maccagnan, Procédure criminelle et défense de l'accusé à la fin de l'Ancien Régime. Etude de la pratique angevine (2010).

${ }^{48}$ According to most historians, he in fact tried to fake the suicide of his son, still considered as offence under the Criminal Ordinance of 1670 and liable to a degrading punishment and confiscation of property. In Letter LXXVI of his Persian Letters published anonymously in 1721, Montesquieu writes: 'Those who kill themselves suffer, as it were, a second death: they are dragged with ignominy through the streets: their infamy is published, and their goods confiscated'.

${ }^{49}$ According to Benoît Garnot, C'est la faute à Voltaire... Une imposture intellectuelle (2009), Voltaire showed little interest in legal and judicial matters and only accepted to defend Jean Calas because it concerned, in his mind, first and foremost religious intolerance.

50 Jean-Pierre Royer, Histoire de la justice, $4^{\text {th }}$ ed. (2010), $153 \mathrm{ff}$.
} 
security when applied to criminal law. Beccaria therefore argues that the effectiveness of criminal justice depends on the certainty of punishments, scaled by the law to the importance of each offence, and he advocates the abolition of capital punishment. ${ }^{51}$ Some French criminalists nevertheless were opposed to the enlightened reform ideas. In his 'Refutation of the hazardous principles exposed in the Treatise on Crimes and Punishments' (1766), Muyart de Vouglans criticizes Beccaria's progressive penology and defends a conservative vision of criminal law and justice, calling for severe and deterrent punishments. He also refutes the idea of social contract and the abolition of the death penalty, although his name appears among the eight advocates who signed a legal consultation in favour of the Chevalier de la Barre. As Muyart de Vouglans, many lawyers, mainly advocates, condemned abuses and excesses, but were not yet prepared to accept radical changes.

Before the intellectual and political fathers of the French Revolution implemented their ideas and proposals, often inspired by England for which they had a deep fascination and which served as a model for many reforms, French enlightened philosophers and political theorists influenced codification or reforms in many countries as Prussia, Austria, Sweden, Russia ${ }^{52}$, not to forget of course the United States. Not surprisingly, no author is more cited by the Committee of Five appointed by the Second Continental Congress to draft the American Declaration of Independence than Montesquieu, whose major book was already translated in English in $1750 .{ }^{53}$

Epilogue

In 1789, the French Revolution swept away Ancien Régime society. In their quest for an ideal society (or Utopia), the revolutionaries sought to reshape the whole society in accordance with the principles of liberty, equality and fraternity. By the decrees of August 1790, the

\footnotetext{
${ }^{51}$ Isabel Ramos Vazquez, 'Cesare Beccaria's On Crimes and Punishments', in Dauchy e.a. (n. 10), 291294 and Marcello Maestro Cesare Beccaria and the origins of penal reform (1973).

${ }^{52}$ Catherine the Great's Nakaz, for example, is permeated with the ideas of the French enlightened philosophers and at least half of its 655 articles have been copied verbatim from Montesquieu's treaty. 'For the benefit of my Empire, I pillaged president Montesquieu without naming him in the text; his book was my breviary', she writes in 1767 to Frederick II of Prussia: Stella Ghervas, 'The Reception of The Spirit of Law in Russia: A History of Ambiguities', in Michel Porret and Catherine Volpilhac-Auger (eds), Le Temps de Montesquieu (2002), 391-403.

${ }^{53}$ Luke Maier, 'The Great Democratic Experiment. Two American Republics guided by Montesquieu and Hume', in Duke Political Science Standard, III. 1 (2013), 1-12.
} 
Constituent Assembly undertook a thorough overhaul of the country's judicial system: courts, legal professions, modes of conflict resolution and even legal education were completely redrawn in compliance with the revolutionary ideology. Arbitration and conciliation were encouraged 'as most reasonable ways to settle disputes between citizens' and the justices of the Peace - not a judge but a pater familias resolving conflicts in equity - became the foundation of a judicial edifice conceived to prevent or avoid disputes rather than settle them. In the new polity imagined by the leading figures of the Revolution - most of them lawyers the implementation of a constitutional and legicentric regime had absolute priority. Legislation expressing the will of the Nation was the only legitimate source of law and under the principle of equality, there could only be one law applicable nationwide and without distinction to all the citizens. Understandably, the 'Legislative assembly' thus became the sole law-making body. As the law, once codified, was meant to foresee everything, judging was stripped down to its leanest form: mechanically enforce legislative prescriptions. The judges - elected among the citizens - were not supposed to interpret the law neither to presume the legislator's intentions, they had to refer systematically to the Legislative Committee in the event of doubt or difficulty.

As a matter of consequence, a general codification of the law is undertaken. In 1791, a criminal code is adopted based on the reform ideas of the enlightened philosophers, in particular the legality principle ${ }^{54}$ which had already been largely popularised by Cesare Beccaria's Dei Delitti e delle Pena. ${ }^{55}$ Yet, a complete codification was not implemented before the early years of the $19^{\text {th }}$ century. The first codes initiated by Napoleon - the Civil Code (1804), the Code of Civil Procedure (1806) and the Commercial Code (1807) - can be portrayed as synthesis of revolutionary and enlightened ideas, of Napoleon's personal vision on what should be the law and the judiciary but also of Ancien Régime legacy. The Napoleonic codes did not wipe the slate clean, nor did they put France's legal and judicial past behind. The Code civil largely draws on provisions of customary and Roman law (the Code's general plan shows great similarities

\footnotetext{
${ }^{54}$ Georges Martyn, Anthony Musson and Heikki Pihlajamäki (eds.), From the Judge's. Arbitrium to the Legality Principle. Legislation as a Source of Law in Criminal Trials, Comparative Studies in Continental and Anglo-American Legal History, 31 (2013); see in particular Sylvain Soleil, 'Lex Imperat: Creation and Exportation of the French Model of Legality Principle (18-19 c.)', 145-168.

${ }^{55}$ Marcello Maestro, Cesare Beccaria and the Origins of Penal Reform (1973).
} 
to the Institutes), ${ }^{56}$ and is indebted to the developments of customary and learned doctrine. Not surprisingly, many articles of the Code civil have been taken verbatim from Pothier's Treatise on obligations that already combined the two expressions of French law (customary law and written law) with the principles of Roman and natural law. ${ }^{57}$ The Code of Civil Procedure likewise cannot deny the legacy of Ancien Régime. Since it entered into force in 1807, the code has unanimously been criticized as a slavish imitation of the Civil Ordinance of 1667 and a restoration of the $18^{\text {th }}$ century procedural practice of the Châtelet court in Paris. As to the Commercial Code, it is often described as an update and adjustment of Colbert's ordinances. The members of the committees responsible for preparing the draft of the different codes were generally, with only a few exceptions, lawyers who had been trained at the Ancien Régime universities and who had practiced as advocates or judges before the French Revolution. Pigeau, for example, the most influential member of the commission in charge of the Code of Civil procedure and also the main author of the project ${ }^{58}$, had even published in 1773 a book entitled La procédure civile du Châtelet et de toutes les juridictions ordinaires du royaume.

It is well established that the these codes were adopted in many countries occupied by the French armies during the Napoleonic wars and exerted a profound influence on the legal system of many civil law countries and their former colonies outside continental Europe in the $19^{\text {th }}$ and $20^{\text {th }}$ centuries, even way to Japan. ${ }^{59}$ The role of the Napoleonic codes as transmission belt for 'ancient' French law has been less emphasized. They did however contribute to the broad dissemination of Ancien Régime principles that historically forged contemporary civil

\footnotetext{
${ }^{56}$ The drafting commission was composed of representatives of the Pays de droit coutumier and Pays de droit écrit. The chairman, Tronchet, was a specialist of the custom of Paris and Portalis, native of Aix-en-Provence where he also studied law, had a very good knowledge of Roman Law.

${ }^{57}$ Pothier's Treatise on Obligations also had a major influence in the area of Common law. The first English translation of Pothier's Treatise on Obligations was published in North-Carolina in 1802, and four years later a second English edition was published in London. In 1950, the American House of Representatives even honoured Pothier as one of the 'historical figures noted for their work in establishing the principles that underlie American law'. Cf. Joseph M. Perillo, 'Robert J. Pothier's Influence on the Common Law of Contracts', in Texas Wesleyan Law Review 11 (2004), 267-290; Rudolf Meyer-Pritzl, 'Robert-Joseph Pothier's Treatise of Obligations', in Dauchy e.a. (n. 10), 288-291.

${ }^{58}$ Pigeau first wrote his own project that was largely approved by the governmental commission chaired by Treilhard: Stefano Solimano, 'Alle origini del Code de procedure civile del 1806: il progetto Pigeau', in Studi di storia del diritto (1999), 729-772.

59 Kazuo Hatoyama, 'The Civil Code of Japan compared with the French Civil Code', in The Yale Law Journal 11, (1902), 296-303 and Charles P. Sherman, 'Debt of Modern Japanese Law to French Law', in California Law Review 6 (1918), 198-202.
} 
law and procedure and can therefore been seen as the most important vector for expanding the legacy of French law in the Early Modern Period.

Select bibliography

Antoine Astaing, Droits et garanties de l'accusé dans le procès criminel d'Ancien Régime : audace et pusillanimité de la doctrine pénale française (1999).

Jean Bart, Histoire du droit privé de la chute de l'Empire romain au XIXe siècle (1998).

Olivier Chaline, Le règne de Louis XIV, 2 vol. (2005)

Serge Dauchy et Véronique Demars-Sion (eds), Les receuils d'arrêts et dictionnaires de jurisprudence, $X V I^{\mathrm{e}}-\mathrm{XVIII}$ siècles (2005).

Bernard Durand, Arbitraire du juge et 'consuetudo delinquendi': La doctrine pénale en Europe du XVIe au XVIII siècle (1993).

François Olivier-Martin, Histoire du droit français des origins à la Révolution, $2^{\text {nd }}$ ed. (1995).

Jean Gaudemet, Les naissances du droit. Le temps, le pouvoir et la science au service du droit (1997)

Jean-Louis Halpérin, L'impossible Code civil (1992).

Jacques Krynen, L'état de la justice en France, XIII $-X X{ }^{e}$ siècles. L'idéologie de la magistrature ancienne (2009)

Jacques Krynen and Bernard d"Alteroche (eds), L'histoire du droit en France. Nouvelles tendances, nouveaux territoires (2014)

Paul Ourliac et Jean-Louis Gazzaniga, Histoire du droit privé français de l'An mil au Code civil (1985)

Albert Rigaudière, Penser et construire l'Etat dans la France du Moyen Age, XIII'-XVe siècle (2003).

Albert Rigaudière, Introduction historique à l'étude du droit et des institutions, $2^{\text {nd }}$ ed. (2005)

Sylvain Soleil, Le Modèle juridique français dans le monde. Une ambition, une expansion, XVI XIXe siècle (2014).

Raoul C. Van Caenegem, Judges, legislators and professors. Chapters in European legal history (1987) 